\title{
VIETNAM ECONOMIC OUTLOOK AFTER COVID-19
}

\author{
Ai Huu Tran \\ My Phan Thi Chieu \\ Thu Nguyen Thi Mong
}

Van Hien University, Ho Chi Minh, Vietnam

Since the beginning of 2020, when the COVID-19 pandemic started spreading across the globe, many businesses had their exports, raw materials supply, and orders interrupted. In Vietnam, with its population of nearly $100 \mathrm{mln}$ people, the domestic market is a large enough space for businesses to overcome difficulties and challenges. Despite the devastating effects of the pandemic on the global economy, the national emerging economy in question has responded well thanks to early actions taken by Vietnamese government. Things are now gradually returning to normal, although a prolonged demand deficit will reduce the potential growth rates in Vietnam and elsewhere.

Keyword: economic outlook; COVID 19 pandemic; economic recovery; Vietnam

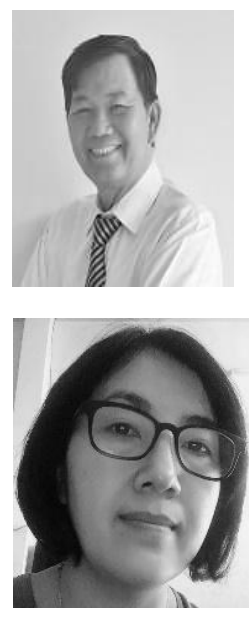

\section{Ai Tran Huu}

PhD, Lecturer of Faculty of Economics, Van Hien University, Ho Chi Minh City, Vietnam. Research interests: markets of agricultural products; SMEs functioning under government support; organic food markets; corporate social responsibility.

E-mail: aith@vhu.edu.vn

\section{My Phan Thi Chieu}

MBA, Lecturer of Faculty of Economics,Van Hien University, Ho Chí Minh City, Vietnam.

Research interests: markets of agricultural products; organic food markets; ecological economics.

E-mail: MyPTC@vhu.edu.vn

\section{Thu Nguyen Thi Mong}

Lecturer of Faculty of Economics, Van Hien University, Ho Chi Minh City, Vietnam Research interests: SMEs functioning and government support, consumer behavior, innovative products markets and finances.

E-mail: aith@vhu.edu.vn 


\section{VIETNAM ECONOMIC OUTLOOK AFTER COVID-19}

\section{Introduction}

Fears about the future of economic growth in the post-pandemic period are widespread. According to the World Bank's assessments, the pandemic has caused the deepest global recession since the World War II. There are at least three reasons behind this crisis.

First, the US and China have been engaged in a trade war since July 2018 after the US President Donald Trump imposed wide-ranging tariffs on China due to its unfair trade practices.

In August 2019, President Trump ordered American companies to "immediately start looking for alternatives to China, including bringing companies back to the United States and making products there."

China has had a similar response, imposing tariffs on many US goods. After a series of negotiations between these two countries, the final negotiation in June 2020 in Hawaii did not produce any breakthrough. This hostile tariff war has fueled an all-out trade war. President Trump has raised tensions, threatening to "cut off the whole relationship with China".

Vietnam's economy is at a stage of rapid and stronger recovery, as compared to some other, neighboring countries in the region, thanks to the relatively low rates of COVID-19 infection spread. However, the remainder of 2021 and the first months of 2022 are forecasted to be challenging, even though the continuation of the much-needed reforms offers a positive medium-term outlook (Impact of the Covid-19 epidemic on the Asian economy, 2020)

In containing the pandemic, Vietnam relies on early action, targeted testing, widespread contact tracing, effective government communications, and broad public engagement and compliance. The International Monetary Fund (IMF) describes Vietnam's virus containment strategy as a "roadmap for other developing countries". The government's swift and effective response meant that non-essential businesses and services were shut down for only 40 days. The early resumption of domestic consumption thanks to various fiscal stimulus measures underpinned the recent Asian Development Bank (ADB) forecast for GDP growth of $4.1 \%$ in 2020 (Impact of Covid 19 on ASEAN+3 economies, 2020). This number is much lower than the pre-pandemic forecast of $6.8 \%$, but it still makes Vietnam one of only two members of the ASEAN that are expected to be growing economically this year.

However, achieving $4.1 \%$ growth for the full year will require a strong second half as well, as Vietnam's economy grew only by $1.8 \%$ in the first half. The $30 \%$ corporate tax cut won't help much as most businesses won't make any profits this year anyway. Likewise, the proposed three-month tax deferral is primarily seen as a window change. Meanwhile, SMEs are finding it difficult to access low-interest credit packages worth VND 16 trln (equivalent to $\$ 10.8 \mathrm{bln}$ ) in total due to strict conditions on collateral and cash flow. According to the General Statistics of Vietnam, nearly 35,000 businesses declared bankruptcy in the first three months of 2020 (Impact on the global production chain of Covid 19, 2020).

Taking into account that the full impact of the shutdown only becomes apparent after it is over, that number is likely to increase significantly in the coming days.

But Vietnam's bigger and upcoming challenge is its reliance on the rest of the world when it comes to fueling domestic growth. Vietnam is the most trade-dependent economy in the Southeast Asia, even more so than Singapore (Duc, 2020). In 2019, its exports and imports accounted for $116 \%$ and $101 \%$ of GDP respectively. With such a high level of trade dependence, Hanoi can only do so much with domestic tools to revitalize its economy. Of 
particular concern to the government is also slow recovery in the United States, as last year the country accounted for about $20 \%$ of Vietnam's total exports.

The pandemic has also been a real blow for Vietnam's tourism industry, which accounts for about 10\% of GDP in 2019 (Anh, 2020). The number of foreign visitors to Vietnam and tourism-related revenues fell by $38 \%$ and $45 \%$ respectively (data as of April 2020 as compared to the same period in 2019). With Hanoi yet to announce the re-entering plans for foreign tourists, there are no guaranteed promises for hotels, food and beverage outlets, travel agents, tour guides and transport staff depending on the so needed flows of tourists.

COVID-19 originated in China and has had a negative impact on Chinese economy in the first place. Vietnam is one of those countries that have been heavily affected because it is an open economy, with a high level of transshipment of goods, services, people, large investments with China, therefore, Vietnamese economy is heavily influenced by Chinese economy.

More specifically, the electronics industry has the largest import-export turnover between Vietnam and China (namely, in such categories as computers, electronic products, and components; phones and components). COVID-19 has been affecting the input supply for production as well as the consumer market of Vietnam's electronics industry, especially the segment of input components for domestic production, thus leading to production costs increase and profits decrease. Other manufacturing industries with input materials also imported from China such as leather and footwear, textiles etc., have been also facing "double" difficulties, both in terms of production input supply and decreasing purchasing power of the huge neighbouring market.

Newly established businesses also decreased their activities in most fields, the strongest decrease has been observed in such areas as art and entertainment (down by 23\%), wholesale and retail sectors (down by 11.8\%) transportation, and warehousing services (down by 37.9\%) (Outlook for Vietnam's economic recovery after the COVID-19, 2020).

Within the transportation industry, air transport has been obviously the most affected one because international passengers using Vietnam's aviation account for nearly $80 \%$ of all international tourists coming to the country. Chinese visitors to Vietnam by air account for $70 \%$ (2019) of all Chinese tourists. Road and rail transport services have been also negatively affected when trade and tourism activities started to decline. Transportation support services have also registered a decrease, such as flight management services, airport services and so on.

\section{Considering the complicated developments of COVID-19, what will be the economic prospects of Vietnam in the near future?}

It is difficult to be certain about any of the potential outlook scenarios because so many elements of the pandemic remain to be still unknown. Will it transform into a new form? Will there be another outbreak? Will asymptomatic carriers spread to humans at some stage in the future? At the moment, we cannot know the answer to any of these questions as each pandemic is by definition new, and very different from all the previous ones.

Currently, Vietnam is experiencing the 4th epidemic wave already, with quite complicated developments. The government is deploying synchronously several strong solutions under the motto of "combining dual goals" - prevention and control of the 


\section{VIETNAM ECONOMIC OUTLOOK AFTER COVID-19}

epidemics. Protection of people's health is the top priority, while socioeconomic recovery and further development are no less important.

The emergence of the whole clusters of cases within the industrial zones in Vietnam is a complicated case, however, localities are closely coordinating their operations with the industrial park management boards and investors while implementing the necessary solutions. Synchronous measures are ensuring production and business activities at factories and enterprises are well controlled, the workers in the industrial zones are isolated at work, or safely transported to ensure minimum exposure to infections outside the community.

Two localities - Vinh Phuc province and Ho Chi Minh City - have been affected by the epidemic the most. Here the common is the practice of the inactive disease prevention in Vietnam.

On May 2, 2021, Vinh Phuc province detected the first case of infection in the community which was the start of the fourth outbreak, but so far, the epidemic situation in the province has been well controlled. When the epidemic broke out, the provincial government established the epidemic prevention points to tighten access to the province, minimizing the movement of people so that they do not spread the disease locally. When the situation was again under control, the province actively introduced programs, hotlines, shuttles, and guidance for workers, following the safety guidelines of the Government and the Ministry of Health.

Ho Chi Minh City is a hot spot of the epidemics in the southern region of Vietnam. In order to realize the "dual goal" (control and prevention at the same time), the city has promptly assessed the conditions to ensure safety in the course of epidemic prevention and control at the enterprises with the motto " 3 places": production on the spot - eats on the spot rest on the spot. The city has been prioritizing all the resources for businesses such as vaccinations for workers, tax exemption, and other incentives.

We can try and predict the state of Vietnam's economy at some point in the future when the wave of infections around the world would be decreased and the overall global situation would be stabilized. The optimistic scenario is that things will more or less return to normal, although a prolonged demand deficit will reduce the future growth rates in Vietnam (and elsewhere).

Thus, the fundamentals of the market will not change and trading will simply return to its usual state.

However, there is also a more pessimistic view on the future. The China-US relationship is perhaps the most important factor in it. If tensions mount, that could increase the desire of many countries to free themselves from supply chains that have proven to be too fragile, and then pursue denuclearization instead. If that happens, there could be some pretty serious challenges for Vietnamese economy (How should Viet Nam deal with the trade war? 2018).

What should Vietnamese government prioritize now to support the economy? For the purposes of comparison and best practices observation, what support packages have been introduced by other countries?

Other governments are introducing stimulus packages designed specifically for their economies, but they all have some elements in common. Some governments are more committed to a more equitable distribution of resources than others. 
Others are facing more resistance from various interest groups that want to ensure they retain control over the majority of government resources. No government is immune to such political and economic pressures.

An important issue to consider would be which sectors are getting the most preferences.

For example, if a government decides to support agriculture, it will also need to support all elements in the agricultural supply chain, the one which delivers agricultural products to shops, restaurants, markets, etc. The same is true for tourism, which requires not only hotels and accommodation overall but also transportation, resort and spa facilities, retail support, personal services and so on.

In general, it would be better to support those industries that have the greatest impact on the overall employment in a country.

\section{Several fiscal and monetary policies have been introduced to support Vietnamese economy. What are the pros and cons?}

Although foreign investments in Vietnam in the first half of this year has been estimated to decrease by $2.5 \%$ (year-on-year), Korean investment alone increased by $43.6 \%$ year-on-year, showing that investment inflows are still relatively steady.

In addition, Vietnam's export turnover in the first half of this year increased by $28.4 \%$, over the same period last year.

Following the growth rate of $2.91 \%$ back in 2020, in the first half of this year, Vietnam recorded the highest economic growth in the region with the growth rate being at the level of 5.64\%. Moreover, due to relatively active export activities and attraction of foreign investments, economic growth has been increasing rather steadily. Vietnam is a typical country that shows some potential for future development, especially with Korean investments currently expanding.

Despite maintaining such a growth momentum, Vietnam is facing many difficulties too. Business environment is still rapidly declining, the number of infected people is peaking at thousand cases per day. Many obstacles are also arising in the production process such as difficulties with labor supply and demand, breaks in raw material supply, increasing logistics costs, etc.

Vietnamese government has generally acted well in supporting the national economy, being aggressive in some situations, and responding early enough to the others. In terms of interest rates, it is unfortunate that the state of the global economy since 2008 and the austerity crisis that followed means that measures such as lowering interest rates are now less effective than they used to be in the past. Interest rates are already very low, almost everywhere in the world, and this means using further cuts as a support tool will be less effective for regulating the economy overall.

As for the labor market, the government has signaled that it will introduce a muchneeded combination of active and passive labor market policies. Passive policies include unemployment benefits so that people can survive for a while without working. Positive policies include providing training and skills development programs that will help people find new types of jobs.

However, no matter what action the government takes here, Vietnam's economy is very open and so its success will depend mostly on what is happening in other countries. If other 
governments do not act in the most productive ways, there is not much a single government can do on its own.

In the long term, there is a need for closer coordination and cooperation within the ASEAN, namely, in part of devising the ASEAN-wide policies to protect its member countries from the crises like the current one.

\section{Conclusion}

Vietnamese policies in the current and the following years would help businesses maintain production and stay now "broken". Enterprises want this support to endure so that once the epidemic ends, they could recover more quickly and easily.

Whatever the future, there will certainly be more new opportunities for development. Be it enterprise level or the macrolevel, all problems must be carefully calculated so that the best solution can be chosen. This is an important factor, especially in the context of competition and trade conflicts that can accelerate capital movement to potential markets. Participation in a new generation FTAs (CPTPP and EVFTA) is also a precondition for Vietnam to expand its market, attract investments and brand new technologies, improve the local business environment, thus promoting growth. economic growth in 2021-2022.

\section{References}

Anh, N. (2020). Vietnamese securities dropped the most in the region because of the COVID-19 flu. Available online at: https://enternews.vn/chung-khoan-viet-giam-manh-nhat-khu-vuc-vi-dichcum-covid-19-166562.html.

Duc, N. (2020). FDI is expected to flow strongly into Vietnam. Available online: https://baodautu.vn/von-fdi-ky-vong-se-chay-manh-vao-viet-nam-sau-dai-dich-covid19d116111.html.

How should Viet Nam deal with the trade war? (2018). Available online at: http://nghiencuuquocte.org/2018/12/10/viet-nam-doi-pho-voi-chien-tranh-thuong-mai/.

Impact of Covid 19 on ASEAN+3 economies. (2020). Special reference document, VNA, February 18.

Impact of the Covid-19 epidemic on the Asian economy. (2020). Special reference document, VNA, February 26.

Impact on the global production chain of Covid 19. (2020). Special reference, VNA, February 20.

Outlook for Vietnam's economic recovery after the COVID-19 (2020). Available online at: https://bnews.vn/trien-vong-phuc-hoi-cua-kinh-te-viet-nam-sau-dich-covid 19/171109.html.

Paper submitted

Paper accepted for publishing

Paper published online
14 August 2021

17 October 2021

30 November 2021 